\title{
Effect of Service Quality on Patient Satisfaction at Graha Juanda Hospital in Bekasi
}

\author{
Ahmad Nurhadi \\ Pamulang University \\ E-mail: dosen01023@unpam.ac.id
}

\begin{abstract}
To improve health services to the community, RS. Graha Juanda Bekasi, as a referral for patients in Bekasi and its surrounding areas, continues to make improvements. This study aims to determine the effect of service quality on patient satisfaction at Graha Juanda Hospital in Bekasi. The method used is explanatory research with a sample of 96 respondents. The analysis technique uses statistical analysis with regression testing, correlation, determination, and hypothesis testing. The results of this research variable Service Quality obtained an average score of 3.40 with good criteria. The patient satisfaction variable obtained an average score of 3.82 with good criteria. Service quality has a significant effect on patient satisfaction with the regression equation $\mathrm{Y}=7.695+0.897 \mathrm{X}$, and a correlation value of 0.784 or strong with a determination of $61.5 \%$. Hypothesis testing obtained a significance of $0.000<0.05$.
\end{abstract}

Keywords: Quality of service; patient satisfaction; hospital

\section{INTRODUCTION}

Nowadays the service sector has experienced very rapid development, such as what happened in the hospitality, insurance, banking, aviation, tourism, and telecommunications service industries. Likewise in the health service industry, whether it is a hospital or a health center so that the business can live and develop, knowledge of good service and trust from patients is required.

The hospital is one of the institutions engaged in the service sector with the responsibility of providing treatment, providing care, seeking patient healing and health, and promoting healthy living education for the community. (Hewagama et al., 2019; Karatepe, 2013; Lystad et al., 2020). The definition of the hospital according to the Decree of the Minister of Health of the Republic of Indonesia Number: 340 / MEN / KES / PER / III / 2010 states that "Hospitals are health service institutions that provide complete individual health services that provide inpatient, outpatient and emergency services. ". Thus the hospital is an institution that provides health services in all fields and types of diseases. The quality of hospital services is very important as a reference in improving services to create customer satisfaction because satisfaction is a central concept in management business discourse (Jasmani et al., 2020; Jasmani \& Sunarsi, 2020; Sunarsi \& Baharuddin, 2019).

Services are actions or activities that can be offered to other parties, which are intangible and do not result in any ownership (Akib \& Ihsan, 2017; Wawointana et al., 2016). At this time the service industry is trying to provide good quality service to attract customers, therefore the 


\section{Jurnal Office: Jurnal Pemikiran Ilmiah dan Pendidikan Administrasi Perkantoran \\ Vol. 6, No. 1, January-June 2020, Page 1-8}

key to success for service companies is good service and the availability of products or services needed by customers as well as improving good service quality (Copuš et al., 2019; Zahlimar et al., 2020).

Actions that must be prioritized by companies in this free market are customer satisfaction, customer satisfaction itself according to (González-Cruz et al., 2019; Kotler, 2000; Netemeyer \& Maxham, 2007) is the feeling of being happy or disappointed by someone that comes after comparing their perceptions or impressions of the performance or results of a product/service or their expectations.

Understanding the fulfillment of customer desires is a requirement for continuous improvement of quality and productivity in achieving total customer satisfaction (Gelbrich et al., 2020; Koch et al., 2020). Fulfilling customer desires is very important in determining the quality of service, because what determines whether or not the quality of service is not the producer or the company but the consumer. The implementation of a company's services in the service sector is to provide the best quality of service (service) to create customer satisfaction. Thus the quality of company services can find out what needs to be improved or improved to achieve the need for customer satisfaction. The large selection of services available makes consumers more likely to make choices according to their perception of certain brands that are their favorite. Companies are competing to expand their market share, trying to attract customers by influencing consumer attitudes to be willing to use their services.

Graha Juanda Hospital Bekasi is one of the hospitals in the Bekasi Regency. The hospital is a type B hospital and is fully accredited with 16 complete services where the city of Bekasi, which is a buffer for the capital city of Jakarta, has made its market share among all levels of society. To improve health services to the community, RS. Graha Juanda Bekasi, as a referral for patients in Bekasi and its surrounding areas, continues to make improvements. This is in line with its vision, "To become a hospital that can provide excellent service, supported by professional and prosperous human resources, adequate infrastructure, and accountable management. Supported by doctors, nurses, special therapy staff, medical technicians, midwifery, nutrition, pharmacy, and other special staff support The mission is to increase the professionalism of human resources, improve human resource welfare, develop infrastructure, develop home service management sick, as well as providing affordable prime services and supported by an adequate health service network. With the support of doctors, personnel, special therapy staff, medical technicians, midwifery, nutrition, pharmacy, and VIP class facilities, I, II, and others, this hospital should be able to compete with other hospitals.

\section{METHOD}

The type of research used is associative, where the aim is to find out how to find the relationship between the independent variable and the dependent variable. The population in this study amounted to 96 respondents at Graha Juanda Hospital in Bekasi. The sampling technique in this study was a saturated sample, where all members of the population were sampled. Thus the sample in this study amounted to 96 respondents. In analyzing the data used 
validity test, reliability test, simple linear regression analysis, correlation coefficient, determination coefficient, and hypothesis testing.

\section{RESULT AND DISCUSSION}

\section{Service Quality}

In this test, it is used to determine the highest minimum and maximum score, the rating score, and the standard deviation of each variable. The results are as follows:

Table 1.

Results of Descriptive Statistics Analysis of Service Quality

Descriptive Statistics

\begin{tabular}{lr|r|r|r|r}
\hline & N & \multicolumn{1}{c|}{ Minimum } & Maximum & \multicolumn{1}{c|}{ Mean } & \multicolumn{1}{c}{ Std. Deviation } \\
\hline Service quality (X) & 96 & 28 & 44 & 34.08 & 3.695 \\
\hline Valid N (listwise) & 96 & & & & \\
\hline
\end{tabular}

Service quality obtained a minimum variance of 28 and a maximum variance of 44 with a rating score of 3.40 with a standard deviation of 3.695 .

\section{Patient Satisfaction}

In this test, it is used to determine the highest minimum and maximum score, the rating score, and the standard deviation of each variable. The results are as follows:

\section{Table 2.}

\section{Results of Descriptive Statistics Analysis of Patient Satisfaction}

\section{Descriptive Statistics}

\begin{tabular}{lr|r|r|r|r}
\hline & \multicolumn{1}{l}{ N } & \multicolumn{1}{c}{ Minimum } & \multicolumn{1}{c|}{ Maximum } & \multicolumn{1}{c}{ Mean } & \multicolumn{1}{c}{ Std. Deviation } \\
\hline Patient Satisfaction (Y) & 96 & 30 & 49 & 38.27 & 4.229 \\
\hline Valid N (listwise) & 96 & & & & \\
\hline
\end{tabular}

Patient satisfaction obtained a minimum variance of 30 and a maximum variance of 49 with a rating score of 3.82 with a standard deviation of 4.229 .

\section{The Effect of Service Quality on Patient Satisfaction}

This analysis aims to determine the effect of the independent variable on the dependent variable. This regression test is intended to determine changes in the dependent variable if the independent variable changes. The test results are as follows: 


\section{4| Jurnal Office: Jurnal Pemikiran Ilmiah dan Pendidikan Administrasi Perkantoran}

Vol. 6, No. 1, January-June 2020, Page 1-8

Table 3.

Simple Linear Regression Test Results

\begin{tabular}{|c|c|c|c|c|c|}
\hline \multirow[b]{3}{*}{ Model } & \multicolumn{2}{|c|}{ Coefficients ${ }^{\mathrm{a}}$} & \multirow{3}{*}{$\begin{array}{l}\text { Standardized } \\
\text { Coefficients } \\
\text { Beta }\end{array}$} & \multirow[b]{3}{*}{$\mathrm{t}$} & \multirow[b]{3}{*}{ Sig. } \\
\hline & \multicolumn{2}{|c|}{$\begin{array}{l}\text { Unstandardized } \\
\text { Coefficients }\end{array}$} & & & \\
\hline & $\mathrm{B}$ & Std. Error & & & \\
\hline $\begin{array}{ll}1 & \text { (Constant) }\end{array}$ & 7.695 & 2.512 & & 3.063 & .003 \\
\hline Service quality $(\mathrm{X})$ & .897 & .073 & .784 & 12.242 & .000 \\
\hline
\end{tabular}

a. Dependent Variable: Patient Satisfaction (Y)

Based on the test results in the table above, the regression equation $Y=7,695+0.897 \mathrm{X}$ is obtained. From the equation, it is explained that a constant of 7,695 means that if the quality of service and motivation is not there, then there is a patient satisfaction value of 7,695 points; Service Quality regression coefficient of 0.897 , this number is positive, meaning that every time there is an increase in Service Quality of 0.897 , patient satisfaction will also increase by 0.897 points.

Correlation coefficient analysis is intended to determine the level of the strength of the relationship between the independent variable and the dependent variable either partially or simultaneously. The test results are as follows:

Table 4.

Results of Testing the Correlation Coefficient of Service Quality on Patient Satisfaction

Correlations $^{\text {b }}$

\begin{tabular}{llr|r}
\hline & & $\begin{array}{c}\text { Service quality } \\
(\mathrm{X})\end{array}$ & \multicolumn{1}{c}{$\begin{array}{c}\text { Patient } \\
\text { Satisfaction (Y) }\end{array}$} \\
\hline Service quality (X) & Pearson Correlation & 1 & $.784^{* *}$ \\
\cline { 2 - 4 } & Sig. (2-tailed) & & .000 \\
\hline Patient Satisfaction (Y) & Pearson Correlation & $.784^{* *}$ & 1 \\
\cline { 2 - 4 } & Sig. (2-tailed) & .000 & \\
\hline
\end{tabular}

**. Correlation is significant at the 0.01 level (2-tailed).

b. Listwise $\mathrm{N}=96$

Based on the test results obtained a correlation value of 0.784 means that service quality has a strong relationship with patient satisfaction.

Analysis of the coefficient of determination is intended to determine the percentage of influence of the independent variable on the dependent variable. The test results are as follows: 
Table 5.

Results of Testing the Coefficient of Determination of Service Quality on Patient Satisfaction

\begin{tabular}{|c|c|c|c|c|}
\hline \multicolumn{5}{|c|}{ Model Summary } \\
\hline Model & $\mathrm{R}$ & R Square & Adjusted R Square & Std. Error of the Estimate \\
\hline 1 & $.784^{\mathrm{a}}$ & .615 & .610 & 2.639 \\
\hline
\end{tabular}

Based on the test results, it was found that the value of determination was 0.615 , which means that the service quality had an influential contribution of $61.5 \%$ to patient satisfaction.

Hypothesis testing with the t-test is used to determine which hypothesis is accepted. The formulation of the hypothesis found that there was a significant influence between service quality and patient satisfaction.

Table 6.

Hypothesis Test Results of Service Quality on Patient Satisfaction

Coefficients $^{\mathrm{a}}$

\begin{tabular}{|c|c|c|c|c|c|c|}
\hline \multirow{2}{*}{\multicolumn{2}{|c|}{ Model }} & \multicolumn{2}{|c|}{$\begin{array}{c}\text { Unstandardized } \\
\text { Coefficients }\end{array}$} & \multirow{2}{*}{$\begin{array}{l}\text { Standardized } \\
\text { Coefficients } \\
\text { Beta }\end{array}$} & \multirow[b]{2}{*}{$\mathrm{t}$} & \multirow[b]{2}{*}{ Sig. } \\
\hline & & $\mathrm{B}$ & Std. Error & & & \\
\hline & (Constant) & 7.695 & 2.512 & & 3.063 & .003 \\
\hline & Service quality (X) & .897 & .073 & .784 & 12.242 & .000 \\
\hline
\end{tabular}

a. Dependent Variable: Patient Satisfaction (Y)

Based on the test results in the table above, the value of $t$ count $>t$ table or $(12,242>1,986)$ is obtained, thus the hypothesis that there is a significant effect between service quality on patient satisfaction is accepted.

\section{Discussion}

\section{Service Quality}

Based on the respondent's answer, the Service Quality variable obtained a rating score of 3.40 in the scale range from 3.40 to 4.19 with good or agree on criteria.

\section{Patient Satisfaction}

Based on the respondents' answers, the Patient Satisfaction variable obtained a rating score of 3.82 in the scale range from 3.40 to 4.19 with good or agree on criteria.

\section{The Effect of Service Quality on Patient Satisfaction}

Service quality has a significant effect on patient satisfaction with the regression equation $\mathrm{Y}=17.517+0.565 \mathrm{X}$, the correlation value is 0.784 or has a strong relationship with the contribution of the effect of $61.5 \%$. Hypothesis testing obtained the value of $t$ count $>t$ table or 


\section{6| Jurnal Office: Jurnal Pemikiran Ilmiah dan Pendidikan Administrasi Perkantoran \\ Vol. 6, No. 1, January-June 2020, Page 1-8}

$(12,242>1,986)$. Thus the hypothesis proposed that there is a significant effect between Service Quality and Patient Satisfaction is accepted.

\section{CONCLUSION}

Based on the results of the research and discussion above, the conclusions in this study are: 1) The Service Quality Variable obtained a rating score of 3.40 in the scale range $3.40-4.19$ with good or agree criteria; 2) Patient Satisfaction Variable obtained a rating score of 3.82 in the scale range from 3.40 to 4.19 with good or agree on criteria; 3) Service Quality has a significant effect on Patient Satisfaction with the regression equation $\mathrm{Y}=17.517+0.565 \mathrm{X}$, the correlation value is 0.784 or strong and the influence contribution is $61.5 \%$ while the remaining $57.9 \%$ is influenced by other factors. Hypothesis test obtained $t$ value $>t$ table or $(12,242>1,986)$.

\section{REFERENCES}

Akib, H., \& Ihsan, A. (2017). Bureaucratic Reform in Public Service: A Case Study on the One Stop-Integrated Service. Mediterranean Journal of Social Sciences, 8(2), 253-258.

Copuš, L., Šajgalíková, H., \& Wojčák, E. (2019). Organizational Culture and its Motivational Potential in Manufacturing Industry: Subculture Perspective. Procedia Manufacturing, 32, 360-367. https://doi.org/https://doi.org/10.1016/j.promfg.2019.02.226

Gelbrich, K., Hagel, J., \& Orsingher, C. (2020). Emotional support from a digital assistant in technology-mediated services: Effects on customer satisfaction and behavioral persistence. International Journal of Research in Marketing. https://doi.org/https://doi.org/10.1016/j.ijresmar.2020.06.004

González-Cruz, T. F., Botella-Carrubi, D., \& Martínez-Fuentes, C. M. (2019). Supervisor leadership style, employee regulatory focus, and leadership performance: A perspectivism approach. Journal of Business Research, 101, 660-667. https://doi.org/https://doi.org/10.1016/j.jbusres.2019.01.065

Hewagama, G., Boxall, P., Cheung, G., \& Hutchison, A. (2019). Service recovery through empowerment? HRM, employee performance and job satisfaction in hotels. International Journal of Hospitality Management, 81, 73-82. https://doi.org/https://doi.org/10.1016/j.ijhm.2019.03.006

Jasmani, J., \& Sunarsi, D. (2020). The Influence of Product Mix, Promotion Mix and Brand Image on Consumer Purchasing Decisions of Sari Roti Products in South Tangerang. PINISI Discretion Review, 1(1), 165-174.

Jasmani, J., Sutiman, S., \& Sunarsi, D. (2020). Analysis of the Effect of Prices, Promotions and Products on Purchase Interest Impacts on Consumer Satisfaction of VIVO Brand Mobile Phones in South Tangerang Region. Jurnal Ad'ministrare, 7(1), 73-82. 
Karatepe, O. M. (2013). High-performance work practices and hotel employee performance: The mediation of work engagement. International Journal of Hospitality Management, 32, 132-140. https://doi.org/https://doi.org/10.1016/j.ijhm.2012.05.003

Koch, J., Gerdt, S.-O., \& Schewe, G. (2020). Determinants of sustainable behavior of firms and the consequences for customer satisfaction in hospitality. International Journal of Hospitality Management, 89 https://doi.org/https://doi.org/10.1016/j.ijhm.2020.102515

Kotler, P. (2000). Marketing Management, Millenium Edition. Marketing Management. https://doi.org/10.1016/0024-6301(90)90145-T

Lystad, R. P., Rapport, F., Bleasel, A., Herkes, G., Nikpour, A., \& Mitchell, R. (2020). Hospital service utilization trajectories of individuals living with epilepsy in New South Wales, Australia, 2012-2016: A population-based study. Epilepsy \& Behavior, 105, 106941. https://doi.org/https://doi.org/10.1016/j.yebeh.2020.106941

Netemeyer, R. G., \& Maxham, J. G. (2007). Employee versus supervisor ratings of performance in the retail customer service sector: Differences in predictive validity for customer outcomes. Journal of Retailing, 83(1), 131-145. https://doi.org/https://doi.org/10.1016/j.jretai.2006.10.009

Sunarsi, D., \& Baharuddin, A. (2019). The Effect of Service Quality and Price Accuracy on Consumer Confidence and Implications for Sales Increase. PINISI Discretion Review, $3(2), 101-110$.

Wawointana, T., Akib, H., Tahmir, S., \& Kerebungu, F. (2016). Role of Local Institutions "Mapalus" as a Basis of Public Service in the Field of Security and Public Order in Minahasa, Indonesia. The Social Sciences, 11(13), 3370-3374.

Zahlimar, Zuriati, Z., \& Chiew, L. (2020). Relationship quality of health services with satisfaction of patients in H. Hanafie Muara Bungo Hospital in 2019. Enfermería Clínica, 30, 168-170. https://doi.org/https://doi.org/10.1016/j.enfcli.2019.11.047 
8| Jurnal Office: Jurnal Pemikiran Ilmiah dan Pendidikan Administrasi Perkantoran Vol. 6, No. 1, January-June 2020, Page 1-8 